\title{
Transatlantic wood pellet trade demonstrates telecoupled benefits
}

\author{
Esther S. Parish $^{1,2}, \underline{\text { Anna J. Herzberger }}^{3}$, Colin C. Phifer $^{4}$ and Virginia H. Dale $^{1,5}$
}

\begin{abstract}
European demand for renewable energy resources has led to rapidly increasing transatlantic exports of wood pellets from the southeastern United States (SE US) since 2009. Disagreements have arisen over the global greenhouse gas reductions associated with replacing coal with wood, and groups on both sides of the Atlantic Ocean have raised concerns that increasing biomass exports might negatively affect SE US forests and the ecosystem services they provide. We use the telecoupling framework to test assertions that the intended benefits of the wood pellet trade for Europe might be offset by negative consequences in the SE US. Through a review of current literature and available data sets, we characterize the observed and potential changes in the environmental, social, and economic components of the sending and receiving regions to assess the overall sustainability of this renewable energy system. We conclude that the observed transatlantic wood pellet trade is an example of a mutually beneficial telecoupled system with the potential to provide environmental and socioeconomic benefits in both the SE US and Europe despite some negative effects on the coal industry. We recommend continued monitoring of this telecoupled system to quantify the environmental, social, and economic interactions and effects in the sending, receiving, and spillover systems over time so that evidence-based policy decisions can be made with regard to the sustainability of this renewable energy pathway.
\end{abstract}

Key Words: bioenergy; biopower; climate change; ecosystem services; Europe; forest management; renewable energy; Southeast US; sustainability; wood pellets

\section{INTRODUCTION}

Integration of multiple disciplinary specifics into a holistic perspective is essential to advance society toward an ultimate goal of sustainable energy production, meaning energy production that can benefit current human populations without adversely affecting future human communities or their environments. Although many people have investigated the potential carbon savings associated with the transatlantic wood pellet trade that fuels European biopower facilities, there is little research that considers the combined environmental and socioeconomic costs and benefits of this renewable energy trade on both sides of the Atlantic Ocean. Such a comprehensive perspective is necessary to support evidence-based decisions, monitoring plans, and policies related to this controversial renewable energy pathway (NRDC 2015, Olesen et al. 2016, Cornwall 2017).

Teleconnections refer to causal connections or correlations between environmental phenomena that occur across large distances, and globalization has been used to examine socioeconomic effects across large distances. Building on both of these concepts, the telecoupling framework proposed by Liu et al. (2013) facilitates identification and characterization of the drivers that connect coupled human and natural systems separated by great distances, and their associated environmental and socioeconomic effects. The telecoupling framework, therefore, offers an ideal lens for examining the connectedness and sustainability of the systems involved in the transatlantic wood pellet trade. Previous studies of the wood pellet trade have focused on carbon accounting aspects of combusting this renewable fuel resource in place of fossil fuel, an issue that is complicated by the fact that fossil fuels are used at various stages of the wood pellet supply chain (Dwivedi et al. 2011, 2014, Krč et al. 2016). However, we have not found studies addressing environmental, social, and economic effects of the transatlantic wood pellet trade in a holistic and systematic way.
Here, we explore assertions that there will be unintended negative environmental and socioeconomic consequences on the southeastern United States (SE US) sending system as a result of wood pellet trade to Europe (NRDC 2015, Olesen et al. 2016, Cornwall 2017). In addition, we use the telecoupling framework to consider negative consequences that might occur outside the geographic boundaries of either the sending or receiving systems (i.e., within a "spillover system"). Through this case study, we seek to improve the understanding of interactions and consequences of the transatlantic wood pellet trade and to lay the groundwork for future quantitative modeling of ways in which this renewable energy pathway might be made more sustainable.

\section{CASE STUDY APPLICATION OF THE TELECOUPLING FRAMEWORK}

Society is increasingly looking to renewable energy production as a way to mitigate global climate change while simultaneously improving local environmental and socioeconomic conditions. To expand their renewable energy portfolios, 27 member states of the European Union (EU) established targets of 20\% renewable energy consumption by 2020 and $27 \%$ by 2030 (European Parliament 2009; European Commission 2030 energy strategy: https://ec.europa.eu/energy/en/topics/energy-strategy-and-energyunion/2030-energy-strategy). Initial EU renewable energy targets became binding in 2009, and a combination of legislation and national incentives spurred several European industrial power plants to begin combusting wood pellets in place of coal.

A confluence of interacting factors has led to rapidly increasing transatlantic exports of wood pellets from the heavily forested SE US to several European nations. These factors include increasing renewable energy demand, limited European forest resources, and controversial greenhouse gas (GHG) accounting practices that have codified biomass energy as carbon neutral in EU member states, effectively allowing energy producers to ignore GHG emissions from wood at the point of combustion (EASAC 2017).

${ }^{1}$ Oak Ridge National Laboratory, ${ }^{2}$ University of Tennessee Bredesen Center, ${ }^{3}$ Department of Fisheries and Wildlife, Center for Systems Integration and Sustainability, Michigan State University, ${ }^{4}$ School of Forest Resources and Environmental Science, Michigan Technological University, ${ }^{5}$ University of Tennessee 
As the transatlantic wood pellet trade has increased, concerns have risen over potential effects on SE US forests and the ecosystem services they provide (Olesen et al. 2016). Apprehensions over forest degradation and the loss of bottomland hardwood forests are coupled with concerns about harm to threatened and endangered species (NRDC 2015). Stakeholders on both sides of the Atlantic question whether the desired GHG reductions are being achieved at a global scale via this international trade arrangement (Cornwall 2017).

For this case study, we first use the telecoupling framework (Liu et al. 2013, 2015) to identify the key players (agents), patterns, flows, and processes within this telecoupled trade system to determine if they enhance or compromise progress toward sustainability across distances. After characterizing the sending and receiving systems (including their agents, causes, and effects) and the flows between them, we discuss a geographically distinct spillover system that is potentially affected by the wood pellet trade. We also describe two potential extensions to the telecoupling framework that proved useful during this analysis.

Conceptual model of the transatlantic wood pellet trade system The telecoupling framework includes five major interrelated components: systems, causes, effects, flows, and agents (Liu et al. 2013). Systems refer to interconnected natural and built environments within specific, nonoverlapping, geographic areas. The sending system is the donor or exporter, and the receiving system accepts or imports the traded item (which can be raw materials, intellectual property, tourism, etc.). The spillover system is a geographically distinct system that is affected by and potentially influences both the sending and receiving systems. These three systems interact at multiple scales because of a variety of social, political, technological, and environmental factors that can affect and be affected by components of the systems, even over great distances. Connecting these disparate systems are the flows, which can be products, species, money, or information transferred within or between the systems (e.g., wood pellets). Agents are the final component of this telecoupled framework and act as the stakeholders that affect the flows within and between the connected systems (e.g., EU member states, SE US forest owners).

We first develop a conceptual model of the transatlantic wood pellet trade system (Fig. 1) using the SE US as the sending system, the EU as the receiving system, and the coal industry as the geographically distinct potential spillover system (along with emissions to air and water during transatlantic pellet transport). We focus our research on the sending and receiving systems because data availability is greater for these parts of the telecoupling framework and because the identified spillover system is affected by additional systems that are beyond the scope of this paper. Finally, we discuss the flows, systems, causes, agents, and effects identified through our data analyses and literature review. The application of the telecoupling framework provides a way to examine multiple aspects of sustainability associated with using wood pellets, i.e., facets of social and ecological sustainability other than the carbon emissions tracked through life cycle analyses.

Sending systems, receiving systems, and the flows between them Through analysis of recent U.S. International Trade Commission (USITC) data, we evaluate the transatlantic flows of wood pellets and money involved in this rapidly growing telecoupled system and use the results to refine the understanding of the geographic boundaries of the sending and receiving systems (Tables 1 and 2). Europe as a whole is a large wood pellet producer, and its member states initially intended to meet their 2020 biopower production targets through a combination of wood and agricultural residues (Dwivedi et al. 2011, Goh et al. 2013, Beckman 2015). However, by 2014 , the SE US was supplying $40 \%$ of Europe's 9 million metric tons (MT) of industrial wood pellets (Stewart 2015) and had become the largest external supplier of pellets to the EU (Olesen et al. 2016). By 2015, the United States was exporting pellet volumes three times greater than Canada and five times greater than the Russian Federation (FAO 2017).

Fig. 1. Conceptual model of the transatlantic wood pellet trade system based on the telecoupling framework proposed by Liu et al. (2013). Solid arrows indicate direct flows of materials (wood pellets) and money between the sending system (southeastern United States) and the receiving system (Europe). Dotted arrows indicate potential connections (influences) on the spillover system (coal industry) as well as emissions of greenhouse gases and waste related to transatlantic shipping between the sending and receiving systems.

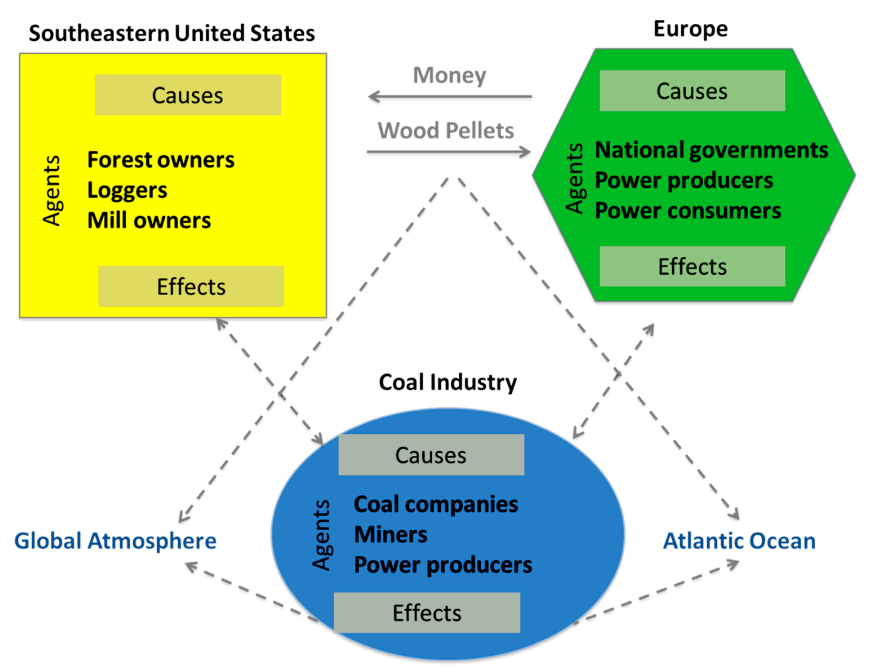

During 2015, the SE US sent 4.6 million MT of wood pellets to 34 countries (Fig. 2). Most $(84 \%$ ) of these pellets were delivered to the UK, $13 \%$ went to Belgium, $1 \%$ went to both the Netherlands and France, and the remaining 1\% of wood pellet exports went to 30 other countries around the globe (USITC 2017). Although the top importers of U.S. wood pellets have fluctuated during each year of record, the UK has been the dominant importer since 2011 and is currently the world's largest importer of wood pellets, while the Netherlands and Belgium have been important importers since 2008 (FAO 2017). USITC (2017) data also show that: (1) these three countries initiated significant imports of this U.S. material after 2007, when the EU pledged to increase its use of renewable energy resources; and (2) the large increase in U.S. wood pellet exports after 2011 has been primarily attributable to the demands of the UK, the Netherlands, and Belgium. Even though the UK has voted to leave the EU, it continues to import 
Table 1. Interacting subsystems within the telecoupled transatlantic wood pellet trade system.

\begin{tabular}{|c|c|c|}
\hline Subsystem & Description & Source of information \\
\hline Sending system & $\begin{array}{l}\text { Southeastern United States, including public and private timberland } \\
\text { in nine states bordering the Atlantic Ocean and Gulf of Mexico } \\
\text { (Alabama, Florida, Georgia, Louisiana, Mississippi, North Carolina, } \\
\text { South Carolina, Virginia, Texas), six shipping ports, } 16 \text { export pellet } \\
\text { mills, a variety of wood processing mills, and related transportation } \\
\text { infrastructure (roads, rails, and barges) }\end{array}$ & $\begin{array}{l}\text { Abt et al. (2014), O'Connell et al. (2014), Stewart (2015), } \\
\text { Olesen et al. (2016), analysis of U.S. International Trade } \\
\text { Commission data (USITC 2017) }\end{array}$ \\
\hline Receiving system & $\begin{array}{l}\text { Pellet importing nations of Europe (UK, the Netherlands, Belgium), } \\
\text { power producers, European Union government, and electricity } \\
\text { consumers }\end{array}$ & $\begin{array}{l}\text { European Parliament (2009), Goh et al. (2013), Dwivedi } \\
\text { et al. (2014), Beckman (2015), analysis of U.S. } \\
\text { International Trade Commission data (USITC 2017) }\end{array}$ \\
\hline Spillover system & Coal industry & $\begin{array}{l}\text { Drax Biomass (2016b), Voegele (2016), analysis of U.S. } \\
\text { International Trade Commission data (USITC 2017) }\end{array}$ \\
\hline Spillover system & Atlantic ocean (barge traffic) & Dwivedi et al. (2014) \\
\hline Spillover system & Global atmosphere (carbon emissions) & Dwived et al. (2014), Morrison and Golden (2016) \\
\hline
\end{tabular}

pellets in accordance with the long-term contracts established by several large power producers and achieved record pellet imports of 4.2 MT from the United States in 2016 (USITC 2017). The Netherlands has recently stopped importing U.S. pellets while deciding on new sustainability requirements (Fig. 2) but is expected to resume shipments once certification programs are implemented (Kotrba 2017). We therefore designate these three European countries (UK, the Netherlands, and Belgium) as the primary receiving system.

Fig. 2. Annual total U.S. wood pellet exports to all countries from 1996 to 2016 (USITC 2017). In 2012, a new stand-alone Harmonized Trade Schedule (HTS) code 4401310000 was introduced for "Wood pellets," but previously, wood pellets were included in HTS code 4401300000, "Sawdust and wood waste or scrap, whether or not agglomerated in logs, briquettes, pellets or similar forms." The line shows changes in HTS code 4401300000 before 2012 and in HTS code 4401310000 for 2012 and years thereafter.

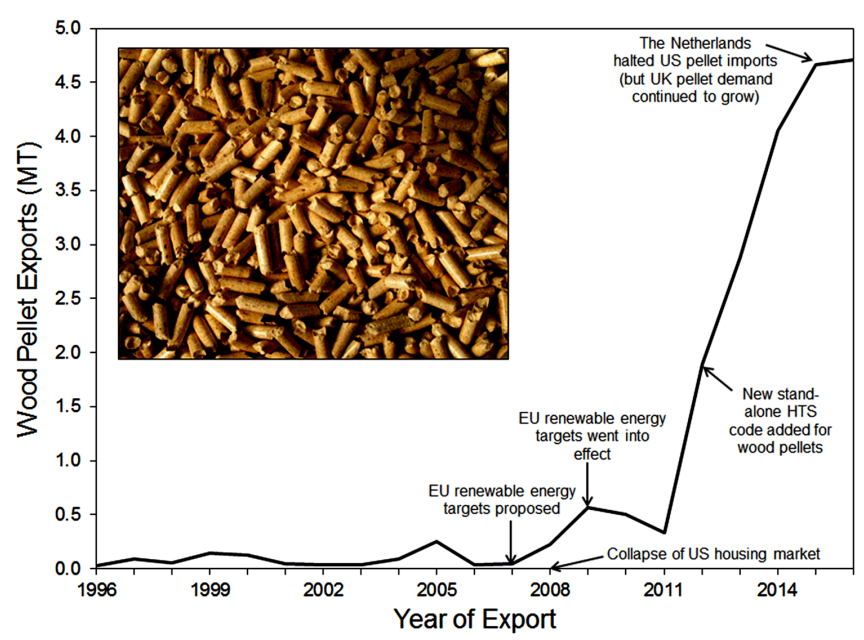

Nearly all U.S. wood pellet exports to Europe are shipped from six SE US ports (Fig. 3). Total wood pellet exports from these six SE US ports more than doubled from 1.9 million MT in 2012 to 4.7 MT in 2015 (USITC 2017). These industrial-grade pellets were
Fig. 3. Map of the southeastern U.S. sending system. Nearly all 2015 U.S. industrial wood pellet exports were shipped to Europe from six ports located on the coasts of Virginia (28\%), Georgia (28\%), Florida (14\%), Alabama (13\%), Texas (10\%), and Louisiana (5\%; USITC 2016). The wood pellets were delivered to these ports from 16 export pellet mills, which obtained their woody materials from forests and saw timber mills within a $120 \mathrm{~km}$ radius (Stewart 2015). The majority of southeastern U.S. forests are privately owned by families (Forest Service Research Data Archive ownership data layer accessed 26 November 2016).

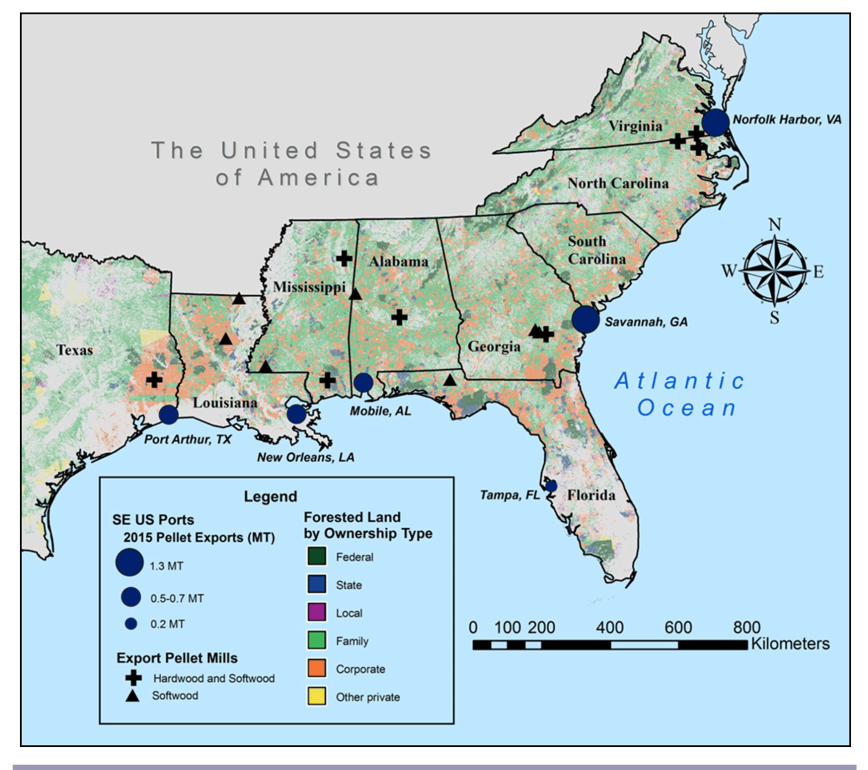

composed of wood materials obtained from timberland and saw timber mills and processed by nearby dedicated export pellet mills. Timberland is a subset of U.S. forestland that is "producing or is capable of producing crops of industrial wood and [is] not withdrawn from timber utilization by statute or administrative regulation" (O'Connell et al. 2014). We therefore define the SE US sending system as the timberlands, saw timber mills, export pellets mills, and transportation systems in the nine states 
Table 2. Flow components of the telecoupled transatlantic wood pellet trade system. Xs indicate the systems (Table 1) that are most closely related to each component attribute.

\begin{tabular}{|c|c|c|c|c|c|}
\hline \multirow[t]{2}{*}{ Flow component } & \multirow[t]{2}{*}{ Attributes } & \multirow[t]{2}{*}{ Source of information } & \multicolumn{3}{|c|}{ Related system } \\
\hline & & & Sending & Receiving & Spillover \\
\hline Wood pellets & $\begin{array}{l}\text { Directly harvested biomass (e.g., forest } \\
\text { thinnings, cull trees, trees for which there is } \\
\text { no other market) }\end{array}$ & $\begin{array}{l}\text { Stewart (2015), Anderson and Mitchell } \\
\text { (2016), Morrison and Golden (2016) }\end{array}$ & $\mathrm{X}$ & $\mathrm{X}$ & \\
\hline Wood pellets & $\begin{array}{l}\text { Indirectly obtained woody biomass (e.g., } \\
\text { sawmill residues) }\end{array}$ & $\begin{array}{l}\text { Stewart (2015), Anderson and Mitchell } \\
\text { (2016), Morrison and Golden (2016) }\end{array}$ & $\mathrm{X}$ & $\mathrm{X}$ & \\
\hline Money & Pellet purchase price & $\begin{array}{l}\text { Goh et al. (2013), Green (2015), Stewart } \\
\text { (2015), analysis of international trade data } \\
\text { (FAO 2017) }\end{array}$ & $\mathrm{X}$ & $\mathrm{X}$ & $\mathrm{X}$ \\
\hline Money & European Union renewable energy credits & Dwivedi et al. (2014), Stewart (2015) & $\mathrm{X}$ & $\mathrm{X}$ & $\mathrm{X}$ \\
\hline Money & $\begin{array}{l}\text { Forest owner income from bioenergy product } \\
\text { sales }\end{array}$ & Malmsheimer and Ferhnolz (2015) & $\mathrm{X}$ & & \\
\hline
\end{tabular}

bordering the Atlantic Ocean that provide wood pellets to Europe: Alabama, Florida, Georgia, Louisiana, Mississippi, North Carolina, South Carolina, Virginia, and eastern Texas (Fig. 3). The transportation infrastructure within the sending system includes road networks, railroads, river barges, and shipping ports.

The first two SE US export wood pellet mills began operating in 2008 , and there were 16 operational export wood pellet mills, with 3 more under construction, in 2016 (Stewart 2015). Generally, these mills obtain biomass for the wood pellets from sawmill residues and other leftovers from higher value wood products (Morrison and Golden 2018). However, biomass for wood pellet production is also obtained directly from forests via thinning of tops, cull trees and brush, downed woody debris, and roundwood (logs) obtained from forests stranded from the market after pulp mill closures (Dale et al. 2017b, Parish et al. 2017b). Through their interviews with SE US pellet industry representatives, Morrison and Golden (2018) found that SE US pellet production scenarios range anywhere from $100 \%$ sawmill residues to $100 \%$ roundwood, fluctuating with available supply and demand.

The reported total export value of SE US wood pellets was $\$ 258$ million in 2012, \$371 million in 2013, \$519 million in 2014, and $\$ 683$ million in 2015 (USD; FAO 2017). Industrial pellets are mostly traded with European nations under long-term bilateral fixed contracts (Goh et al. 2013). In the short term, pellet prices may be influenced by general wood market supply and demand trends, currency exchange rates, and disruptive events such as the heavy winter rains of 2009 and 2013 that prevented planned SE US tree harvests (Stewart 2015). Export wood pellet demand has not yet caused any significant price changes for other U.S. wood products, but bioenergy production has caused some local competition for pulpwood (Stewart 2015). However, as the U.S. housing market continues to recover from the 2008 crash, additional high-value saw timber will be harvested and processed, thereby leading to greater availability of lower value pulpwood and residues (Parish et al. 2017b).

\section{Causes of recent growth in the wood pellet trade}

The transatlantic wood pellet trade has accelerated because of a variety of causes (Table 3). The EU government is the main driver of the trade, through both its Renewable Energy Directive and its incentive programs (Dwivedi et al. 2014). European nations have been seeking to mitigate climate change through the reduction of GHG emissions from existing coal-powered electricity plants (Intergovernmental Panel on Climate Change 2014). The natural gas infrastructure and pipelines in Europe are not as developed as they are in the United States, making the option of gas-fired power too expensive within that region (Xian et al. 2015). The European Commission has identified wood pellets as the most economical way to convert biomass materials to fuel to help meet the EU's renewable energy goals (Beckman 2015), and wood pellets have a higher thermal energy content than typical biomass sources because they are produced through compression (U.S. Department of Commerce International Trade Administration 2016). As a response to the EU's 2020 climate and renewable energy targets, national legislations and regulations provided monetary incentives to owners of biomass-based power plants (Dwivedi et al. 2011, Goh et al. 2013, EASAC 2017). The engineering necessary to retrofit an existing coal power plant to use biomass, either alone or through cofiring, is relatively simple, and the low cost of plant conversion helps make biomass an important bridge fuel for European power suppliers (Morrison and Golden 2018).

Industrial wood pellet trade flows are influenced by European power plant specifications for size and quality (e.g., low ash content), which affect wood inputs as well as processing techniques (Anderson and Mitchell 2016). Although EU member states increasingly have opportunities to purchase wood pellets from nearby countries, the high quality of U.S. wood pellets coupled with their relatively lower cost of transportation over water (relative to land) make U.S. wood pellets an attractive import commodity (Beckman 2015).

Although the rise in U.S. wood pellet exports has been primarily driven by increased European demand, geography, economics, and other factors within the SE US system have contributed to the growth in trade. The temperate climate of the SE US supports abundant forests that regenerate quickly. Known as the nation's "woodbasket," the SE US region contains $40 \%$ of the 211 million ha of timberland found across the United States and has supplied about $63 \%$ of U.S. timber harvests since 1996 (Oswalt and Smith 2014, Langholtz et al. 2016). The proximity of large amounts of this forested land to the Atlantic Ocean (Fig. 3) enables low-cost 
Table 3. Causal components of the telecoupled transatlantic wood pellet trade system. Xs indicate the systems (Table 1) that are most closely related to each component attribute.

\begin{tabular}{|c|c|c|c|c|c|}
\hline \multirow{2}{*}{$\begin{array}{l}\text { Causal } \\
\text { components }\end{array}$} & \multirow[t]{2}{*}{ Attributes } & \multirow[t]{2}{*}{ Source of information } & \multicolumn{3}{|c|}{ Related system } \\
\hline & & & Sending & Receiving & Spillover \\
\hline Socioeconomic & U.S. housing market collapse $\sim 2008$ & Malmsheimer and Ferhnolz (2015), Stewart (2015) & $\mathrm{X}$ & & \\
\hline Socioeconomic & Decline in U.S. pulp and paper industries & $\begin{array}{l}\text { Goh et al. (2013), Stewart (2015), World Biomass } \\
\text { (2015), Brandeis and Guo (2016) }\end{array}$ & $\mathrm{X}$ & & \\
\hline Socioeconomic & Lack of a U.S. biopower market & Xian e al. (2015), Mei and Weitzstein (2017) & $\mathrm{X}$ & & \\
\hline Socioeconomic & $\begin{array}{l}\text { Availability of low-cost natural gas in the } \\
\text { United States and not in Europe }\end{array}$ & $\begin{array}{l}\text { Xian et al. (2015), Breen and Koehler (2017), Mei } \\
\text { and Wetzstein (2017) }\end{array}$ & $\mathrm{X}$ & $\mathrm{X}$ & \\
\hline Socioeconomic & $\begin{array}{l}\text { Low cost of transatlantic shipments and } \\
\text { dedicated shipping lanes }\end{array}$ & Dwivedi et al. (2014), Rodrique (2016) & $\mathrm{X}$ & $\mathrm{X}$ & $\mathrm{X}$ \\
\hline Socioeconomic & $\begin{array}{l}\text { European demand for high-grade (e.g., low } \\
\text { ash content), low-cost wood pellets }\end{array}$ & $\begin{array}{l}\text { Abt et al. (2014), Beckman (2015), Olesen et al. } \\
\text { (2016) }\end{array}$ & $\mathrm{X}$ & $\mathrm{X}$ & \\
\hline Socioeconomic & $\begin{array}{l}\text { Relatively low cost of retrofitting coal plants } \\
\text { to enable biomass cofiring }\end{array}$ & $\begin{array}{l}\text { Morrison and Golden (2016), Mei and Wetzstein } \\
\text { (2017) }\end{array}$ & & $\mathrm{X}$ & \\
\hline Political & $\begin{array}{l}\text { European Union climate and renewable } \\
\text { energy goals }\end{array}$ & $\begin{array}{l}\text { Directive 2009/28/EC of the European Parliament } \\
\text { (European Commission 2009), European } \\
\text { Commission } 2030 \text { energy strategy (https://ec. } \\
\text { europa.eu/energy/en/topics/energy-strategy-and- } \\
\text { energy-union/2030-energy-strategy) }\end{array}$ & & $\mathrm{X}$ & \\
\hline Political & $\begin{array}{l}\text { Wood energy plans and subsidies by } \\
\text { European Union member states }\end{array}$ & Dwivedi et al. (2014), EASAC (2017) & $\mathrm{X}$ & $\mathrm{X}$ & $\mathrm{X}$ \\
\hline Political & $\begin{array}{l}\text { U.S. coal industry opposition to proposed U. } \\
\text { S. Clean Power Plan }\end{array}$ & $\begin{array}{l}\text { Personal communication to E. S. Parish from } \\
\text { attendees of the Appalachian Wood Energy } \\
\text { Innovations Conference on } 24 \text { August } 2016\end{array}$ & $\mathrm{X}$ & & $\mathrm{X}$ \\
\hline Environmental & $\begin{array}{l}\text { Downed wood available following insect } \\
\text { outbreaks, tornadoes, ice storms, and other } \\
\text { extreme events }\end{array}$ & Wear et al. (2013), Greenberg and Collins (2016) & $\mathrm{X}$ & & $\mathrm{X}$ \\
\hline Geographic & $\begin{array}{l}\text { Temperate southeastern U.S. climate, } \\
\text { allowing for rapid forest growth and } \\
\text { regeneration }\end{array}$ & Goh et al. (2013) & $\mathrm{X}$ & $\mathrm{X}$ & \\
\hline Geographic & $\begin{array}{l}\text { Southeastern U.S. forests' proximity to } \\
\text { Atlantic Ocean, enabling direct shipping to } \\
\text { the European Union }\end{array}$ & Goh et al. (2013), Hamilton and Quinlan (2017) & $\mathrm{X}$ & $\mathrm{X}$ & $X$ \\
\hline
\end{tabular}

transportation of woody biomass to Europe via well-established maritime shipping routes (Rodrique 2016, Hamilton and Quinlan 2017). Forest disturbances from insect outbreaks, windstorms, ice storms, and other extreme events yield immediate sources of lowgrade biomass that may be burned or left to decompose without a market outlet (Wear et al. 2013, Greenberg and Collins 2016).

The rise of the digital age around the turn of the 21 st century led to the general decline of the pulp and paper market worldwide. Following the crash of the U.S. housing market in December 2007, nearly 1000 U.S. wood-processing mills were closed (Oswalt and Smith 2014). By 2009, sawmills across the SE US were operating at only $60 \%$ capacity (Stewart 2015), and losses of SE US mills led to a significant loss of jobs throughout the southeastern region (Brandeis and Guo 2016). Alternative wood product pathways are therefore critical to keeping SE US land in forest (Dale et al. 2017a).

At this time, there are no policies in place that specifically inhibit or encourage the use of wood pellets within the United States (Langholtz et al. 2016). Although woody biomass could theoretically be used for local biopower production, the recent drop in U.S. natural gas prices coupled with the lobbying strength of the U.S. coal industry have prevented the development of a SE US market for wood pellets (Xian et al. 2015, Mei and Wetzstein
2017). Bagged wood pellets have been used for home heating in the northeastern United States since the 1930s (Spelter and Toth 2009), but opposition to the U.S. Environmental Protection Agency's Clean Power Plan proposal and lack of incentives have hampered growth of wood-based biopower at an industrial scale (Xian et al. 2015). Thus, U.S. wood pellet exports have far outstripped domestic use over the past several years.

\section{Agents: primary, facilitating, and constraining}

Complex varieties of decision makers are involved in both the sending and receiving systems. We have therefore divided the agents into three subtypes based on the ways they can affect flows within and between the sending, receiving, and spillover systems (Table 4). We define primary agents as the central decision makers within each system that drive flows based on actions and information received from facilitating and constraining agents. Facilitating agents are entities within the system that increase or speed up the flow of material from the system. Constraining agents slow down or reduce the flow of material. Because of the many uncertainties related to future growth and expansion of the international wood pellet trade, we thought it was important to integrate these layered agents into the conceptual model.

Industrial-grade wood pellets for bioenergy are a new commodity within a preexisting U.S. forest sector that is driven by local 
Table 4. Agents within the telecoupled transatlantic wood pellet trade system. Primary agents are the system's key decision makers, facilitating agents tend to increase flows within the system, and constraining agents tend to decrease flows within the system.

\begin{tabular}{|c|c|c|}
\hline Agent type & Sending system & Receiving system \\
\hline Primary agents & $\begin{array}{l}\text { Family forest owners, institutional forest owners, loggers, } \\
\text { mill owners }\end{array}$ & $\begin{array}{l}\text { Governments of European nations and European Union } \\
\text { member states, power producers (e.g., Drax), power } \\
\text { consumers }\end{array}$ \\
\hline Facilitating agents & $\begin{array}{l}\text { Port operators and shipping companies, railroad operators, } \\
\text { truck drivers, owners of mothballed pulp mills, Industrial } \\
\text { Pellet Association, investors, U.S. Department of } \\
\text { Agriculture Forest Service, forestry extension agents from } \\
\text { land-grant universities, forestry associations }\end{array}$ & $\begin{array}{l}\text { European Commission, pellet supply chain operators, } \\
\text { investors }\end{array}$ \\
\hline Constraining agents & $\begin{array}{l}\text { State governments, municipalities, environmental } \\
\text { nongovernmental organizations, citizens' alliances, land } \\
\text { trusts }\end{array}$ & Environmental nongovernmental organizations \\
\hline $\begin{array}{l}\text { Facilitating or } \\
\text { constraining agents }\end{array}$ & $\begin{array}{l}\text { U.S. Environmental Protection Agency, U.S. Fish and } \\
\text { Wildlife Service, forest certification programs }\end{array}$ & $\begin{array}{l}\text { Certification programs specific to the wood pellet industry } \\
\text { (e.g., Sustainable Biomass Partnership) }\end{array}$ \\
\hline
\end{tabular}

demand for the highest value timber product, which is often saw timber but can be pulp, as influenced by location and type of mill (Parish et al. 2017b). The primary agents within the SE US sending system include the forest owners and land managers who make key decisions about timberland management and harvests. The decisions include choices in harvest and rotation length, residue removal rates, and ownership transfer, which may affect forest area, quality, and composition over space and time for many decades.

Recent divestiture of industrial land ownership to private ownership (e.g., International Paper's sale of 1.9 million ha of SE US timberland in 2006) has led to more stand-level management and more flexibility in response to market conditions (Stewart 2015). The majority (i.e., $87 \%$ ) of SE US forest is now privately owned by families (Weir and Greis 2013), many of whom choose when and how to harvest based on personal values and financial considerations coupled with life events such as education or health needs (Butler et al. 2017). Family owners generally have the goal of growing larger, higher value trees, and they frequently delay harvests until the price of saw timber looks favorable (Stewart 2015) or until life events instigate a need for cash (Butler et al. 2017). Hunting and recreation leases also supplement incomes (Malmsheimer and Fernholz 2015) and may influence the type of harvest selected or avoided (e.g., clearcutting, controlled burning).

Loggers and mill owners are also primary agents within the SE US sending system. Certified pellet, pulp, and saw mills require special documentation of logger training and certification from their suppliers to ensure sustainable practices. Both mill operators and forest managers help make decisions regarding when to supply biomass to different portions of the wood products market, including pellet production facility operators.

Transfer of wood material from SE US forest landings to other parts of the supply chain is facilitated by a well-developed infrastructure of railways, road networks, and barges. The Industrial Pellet Association, mothballed paper and pulp mills, and the available workforce through the SE US are additional facilitating agents that encourage the production of wood pellets by making the supply chain components accessible and cost efficient.
Additional facilitating agents within the sending system include personnel from the U.S. Department of Agriculture Forest Service and forestry extension agents from land-grant universities. These entities are charged with educating forest owners concerning forest best management practices (BMPs) and the potential (and often variable) outlets for wood. Forestry associations such as the Society of American Foresters and the National Council for Air and Stream Improvement have a primary responsibility to help implement decisions that will promote a sustainable wood industry over multiple decades and are also currently supportive of the pellet industry. If these entities were to gain new information about the wood pellet industry causing negative impacts on forests, they would alter their advice to forest managers accordingly.

A variety of federal, state, county, and municipal regulations apply to forest management in the SE US (Olesen et al. 2016) and may either directly or indirectly affect the supply of biomass available for the pellet industry. The U.S. Energy Independence and Security Act of 2007 sets renewable fuel specifications for the United States and may begin to affect pellet production if woody biomass starts being used for domestic energy generation (Langholtz et al. 2016). The U.S. Environmental Protection Agency and the U.S. Fish and Wildlife Service are the primary federal regulatory agents in charge of enforcing the Clean Water Act, Endangered Species Act, Migratory Bird Treaty Act, Coastal Zone Management Act, and Lacey Act (USIPA 2013). The U.S. Environmental Protection Agency and the U.S. Fish and Wildlife Service often delegate oversight to individual state governments, which also support a variety of forestry BMPs (Cristan et al. 2016) related to water quality management, soil quality and erosion, wetlands protection, zoning issues, and landscaping ordinances. All of these regulations and BMPs have the potential to constrain pellet production (e.g., through residue removal rate requirements). Land trusts and citizens' alliances are additional constraining agents because they may convert timberland to protected forestland through the establishment of conservation easements (Davis 1996). Some alliances exert political and social pressure to not use wood for energy.

It is currently unclear whether potential new requirements to get all pellet feedstock certified through programs such as the 
Roundtable on Sustainable Bioproducts or the Sustainable Biomass Partnership will increase or decrease SE US export pellet volumes. A recent Dutch study (Kotrba 2017) found that only 5\% of small forest owners in the United States are currently certified by one of the four primary U.S. forest certification programs, namely the Forest Stewardship Council, the American Tree Farm System, the Sustainable Forestry Initiative, and the Programme for the Endorsement of Forest Certification. Although certification programs can help SE US pellet mills satisfy the legal requirements of EU receiving countries, becoming formally certified under one or more of these programs often is too costly or time consuming for many of the small family forest owners who manage $>80 \%$ of SE US timberland (Malmsheimer and Fernholz 2015, Poudyal et al. 2015, Olesen et al. 2016). A recent survey of residents in the state of Georgia found that they are more supportive of environmental management incentives than requirements (Poudyal et al. 2015).

Primary agents within the European receiving system include individual governments, which support the increased use of biomass as a substitute for coal in response to renewable energy targets set by the European Commission (Table 4). Primary agents also include the biomass-using power producers and the power consumers who collectively determine the amount of electricity that needs to be generated as well as fuel types used.

Facilitating agents include the European Commission, which has the power to establish and revise energy legislation and incentives, as well as the individuals who operate within the preexisting pellet supply chain originally set up to receive pellets from within Europe. Constraining agents include environmental nongovernmental organizations (NGOs) on both sides of the Atlantic that oppose the wood pellet trade because of concerns about potential harm to SE US forest biodiversity and ecosystem services (e.g., NRDC 2015).

Within the European receiving system, there are also agents that may be either facilitating or constraining depending on the turn of events. For instance, the Sustainable Biomass Partnership formed in 2013 in conjunction with European utilities intends to facilitate the wood pellet trade via standardized sustainability protocols, but making that program a requirement for doing business with SE US mills may become a hindrance for reasons already discussed. This example demonstrates that agents within the telecoupled system can have effects across system boundaries and over long distances. If and when governmental subsidies for renewable energy are removed, private investors may facilitate or hinder new market development for the wood pellet trade

\section{Effects: observed vs. potential}

Both the recency and relatively small size of wood pellet production within a preexisting wood market system make it difficult to determine the actual effects of this new trade commodity on SE US forest management and related ecosystem services (Parish et al. 2017b). Whereas U.S. wood pellet exports have been growing rapidly during recent years (Fig. 2), they still constitute a relatively small proportion of total SE US timberland removals (see Fig. 5 of Parish et al. 2017a). NGOs are particularly vocal about potential environmental problems that might arise from a growing wood pellet industry (hence their designation as constraining agents in Table 4), but evidence of actual observed impacts is difficult to find, particularly at this early stage of the industry's development. We have therefore distinguished between wood pellet industry effects that have been observed (Table 5) and those that have been speculated (i.e., potential effects; Table 6). We discuss both types of effects.

Concerns have been raised by the European Commission regarding potential environmental effects of the transatlantic wood pellet trade, including: (1) deforestation and forest degradation within the SE US, (2) losses of biodiversity and ecosystem services in SE US forests, and (3) the EU not achieving desired net GHG emissions reductions through substitution of wood pellets for coal. First, there is no evidence that recent pellet production has been responsible for deforestation or forest degradation in the SE US (Dale et al. 2017b). Instead, changes in the amount of SE US land retained in forest, as well as the quality and composition of the forest, continue to be driven largely by development, urban encroachment, natural disturbances, and climate change (Wear and Greis 2013). Although some NGOs argue that species-rich mixed hardwood stands are being replaced by pine plantations because of increased wood demand for energy (NRDC 2015, Olesen et al. 2016), recent analysis of total SE US sawtimber and pulpwood inventory for 2000-2014 showed a $0.1 \%$ annual increase in hardwoods in the Atlantic Region and a 1.3\% annual increase in hardwoods in the Gulf Region (Stewart 2015).

Second, assessing effects of the transatlantic wood pellet trade on SE US biodiversity is difficult because of the small role of pellet production within the larger U.S. wood products system (Parish et al. 2017b) and because effects on biodiversity are highly context specific and depend on particular species and habitats, forest management practices (e.g., rotation intervals, residue removal rates), and forest conditions prior to harvest (Constanza et al. 2016). The same set of conditions may cause some species to decline while others benefit (e.g., some species thrive in younger forests whereas others depend on mature trees). It is important to recognize the SE US region is a mosaic landscape of different forests (in terms of age, stand structure, and species composition) that are managed for multiple objectives with overlapping state and federal guidelines. Negative effects of bioenergy on biodiversity can be avoided or reduced by conservation of priority areas (Joly et al. 2015), and two of the largest SE US pellet producers have recently established conservation funds to help preserve and restore sensitive bottomland forests (Drax Biomass 2016a; Enviva Forest Conservation Fund: http://envivaforestfund. org/).

Ecosystem services are essential forest "products" alongside timber and pulp resources (Anderson and Mitchell 2016), and growing biomass exports have the potential to affect them by changing forest management practices (Janowiak and Webster 2010, Achat et al. 2015, Tarvainen et al. 2015). SE US ecosystem services that could be affected by pellet production (either negatively or positively) include flood control, soil quality, and water purification (NRDC 2015), as well as recreational opportunities for hikers, boaters, and hunters (Malmsheimer and Fernholz 2015). Soil carbon can be affected by forest harvesting, but the degree of effect is highly site dependent, with complex interactions (Achat et al. 2015, Coulston et al. 2015). Forest thinning for biomass harvest can also improve carbon sequestration in maturing trees by increasing stand growth rates (Jandl et al. 2007). Most state-managed forestry BMPs 
Table 5. Observed effects within the telecoupled transatlantic wood pellet trade system. Positive (+), negative (-), and uncertain $(0)$ effects are indicated for each subsystem (Table 1).

\begin{tabular}{|c|c|c|c|c|c|}
\hline \multirow[t]{2}{*}{ Effect type } & \multirow[t]{2}{*}{ Attributes } & \multirow[t]{2}{*}{ Source of information } & \multicolumn{3}{|c|}{ Related system } \\
\hline & & & Sending & Receiving & Spillover \\
\hline Environmental & $\begin{array}{l}\text { Enhanced management of Southeast U.S. (SE US) } \\
\text { forest systems through extra income from bioenergy } \\
\text { products, with resulting benefits to water quality, } \\
\text { biodiversity, carbon sequestration, and forest } \\
\text { productivity }\end{array}$ & $\begin{array}{l}\text { Malmsheimer and Fernholz (2015), Dale et } \\
\text { al. (2017a) }\end{array}$ & + & & \\
\hline Environmental & $\begin{array}{l}\text { Conservation of sensitive SE US forest ecosystems } \\
\text { through funds established by large pellet producers }\end{array}$ & $\begin{array}{l}\text { Drax (2016a), Enviva Forest Conservation } \\
\text { Fund (http://envivaforestfund.org/) }\end{array}$ & + & & \\
\hline Environmental & $\begin{array}{l}\text { Reduction in toxic air emissions related to coal } \\
\text { combustion }\end{array}$ & Rudie et al. (2016) & & + & \\
\hline Environmental & $\begin{array}{l}\text { Reduction in greenhouse gas emissions from energy } \\
\text { production }\end{array}$ & $\begin{array}{l}\text { Goh et al. (2013), Dwived et al. (2014), } \\
\text { Drax (2016b), Morrison and Golden (2016) }\end{array}$ & & 0 & 0 \\
\hline Environmental & $\begin{array}{l}\text { Reduction in air pollution due to reduced burning of } \\
\text { woody debris in the open }\end{array}$ & Evans et al. (2013) & + & & \\
\hline Environmental & $\begin{array}{l}\text { Preservation of European Union forested land and } \\
\text { associated ecosystem services }\end{array}$ & Solberg et al. (2014) & & + & \\
\hline Socioeconomic & $\begin{array}{l}\text { Increased fuel costs for European power producers } \\
\text { (relative to coal) }\end{array}$ & Green (2015) & & - & \\
\hline Socioeconomic & Boiler conversion costs & Green (2015) & & - & \\
\hline Socioeconomic & $\begin{array}{l}\text { Job creation because it takes more labor to generate } \\
\text { electricity from pellet fuel than from coal }\end{array}$ & Strauss (2014) & & + & \\
\hline Socioeconomic & $\begin{array}{l}\text { Additional market opportunity for woody biomass } \\
\text { helps SE US land remain in forest (rather than } \\
\text { succumbing to urbanization pressures) }\end{array}$ & World Biomass (2015), Dale et al. (2017a) & + & & \\
\hline Socioeconomic & Avoided job losses in rural SE US & World Biomass (2015) & + & & \\
\hline Socioeconomic & $\begin{array}{l}\text { Reduced risk of wildfires due to increased forest } \\
\text { management }\end{array}$ & $\begin{array}{l}\text { Neary and Zieroth (2007), Anderson and } \\
\text { Mitchell (2016) }\end{array}$ & + & & \\
\hline Socioeconomic & $\begin{array}{l}\text { Development of international sustainability } \\
\text { certification schemes }\end{array}$ & $\begin{array}{l}\text { Buchholz et al. (2009), Barnett (2016), } \\
\text { Olesen et al. (2016) }\end{array}$ & 0 & 0 & \\
\hline
\end{tabular}

throughout the SE US, and the requirement by many mills that certified loggers do the harvesting, should ensure that water quality and soil quality are maintained because these system actors are also concerned about these potential effects (Cristan et al. 2016, Olesen et al. 2016). Profits from wood pellet exports have provided SE US landowners with additional income needed to keep their land in forests and manage it properly (Malmsheimer and Fernholz 2015, Dale et al. 2017a). This new revenue source for wood products is especially important given the decline in total U.S. wood-based production, which has acute effects in rural US SE communities (Brandeis and Guo 2016, Parish et al. 2017a). Well-managed forests have been shown to improve water quality, carbon sequestration, and biodiversity, as well as overall productivity (Anderson and Mitchell 2016, Dale et al. 2017a).

Third, the transatlantic wood pellet trade was initiated to help European nations reduce their GHG emissions from electricity generation relative to traditional fossil fuel combustion. Several studies, including one that modeled GHG emissions under 930 different scenarios (Dwivedi et al. 2014), have found that overall GHG emissions may be substantially reduced through the use of wood pellets. However, "carbon accounting" continues to be one of the thorniest areas of debate concerning the transatlantic wood pellet trade because of the different assumptions and methods for estimating net GHG emissions (Berndes et al. 2016, EASAC 2017). EU member states that import wood pellets from nations as far away as the United States and Canada are currently able to report GHG emissions reductions of up to $78 \%$ for electricity generation (see Table 97 of Giuntoli et al. 2017), partly because of the controversial accounting practice of assuming that carbon is instantly released to the atmosphere when trees are harvested rather than at the point of combustion (EASAC 2017). In general, the "carbon debt" debate relates to the fact that it takes much longer for trees to regrow and store carbon (i.e., decades) than it does to release carbon from wood via combustion in power plants (Goh et al. 2013). Carbon debt often assumes that the trees would not be harvested except for pellet demand and does not apply to the wood wastes and residues that are often used for pellet production in the SE US. In the absence of a bioenergy market, woody debris from noncommercial thinnings, harvest residues, and some mill residues are more likely to be left in piles to decompose or burned on-site, thereby emitting GHGs with no energy recovery (Evans et al. 2013, Dale et al. 2017a). Forest management through selective thinning has the potential to increase carbon stored in soils and trees (Dale et al. 2017a) while simultaneously providing low-quality roundwood feedstock to pellet mills located within a reasonable distance. The careful consideration of the effects of pellet production compared to what would be expected under a reference "counterfactual scenario" is essential to solving this debate over carbon accounting (Ricardo Energy and Environment 2016, Parish et al. 2017b).

Partly because of sustainability concerns from European and $\mathrm{U}$. S. NGOs, a certification program specifically intended for wood for energy was started in 2013. This Sustainable Biomass Partnership is industry led and is supported by European utilities 
Table 6. Potential effects of the telecoupled transatlantic wood pellet trade system. Positive $(+)$, negative $(-)$, and uncertain $(0)$ effects are indicated for each subsystem (Table 1).

\begin{tabular}{|c|c|c|c|c|c|}
\hline \multirow[t]{2}{*}{ Potential effect type } & \multirow[t]{2}{*}{ Attributes } & \multirow[t]{2}{*}{ Source of information } & \multicolumn{3}{|c|}{ Related system } \\
\hline & & & Sending & Receiving & Spillover \\
\hline Environmental & $\begin{array}{l}\text { Increased pressure on threatened and endangered } \\
\text { Southeast U.S. (SE US) forest species, either directly } \\
\text { through changes to forest habitat (e.g., conversion of } \\
\text { hardwood to pine plantations) or indirectly through } \\
\text { altered management practices (e.g., removal of debris or } \\
\text { snags, altered rotation intervals) }\end{array}$ & $\begin{array}{l}\text { Fritts et al. (2015), Hanula et al. } \\
\text { (2015), NRDC (2015), Olesen et al. } \\
(2016)\end{array}$ & - & & \\
\hline Environmental & $\begin{array}{l}\text { Loss of ecosystem services from SE US forests (e.g., } \\
\text { flood protection, soil stabilization, carbon } \\
\text { sequestration) }\end{array}$ & $\begin{array}{l}\text { Janowiak and Webster (2010), NRDC } \\
\text { (2015), Tarvainen et al. (2015) }\end{array}$ & - & & \\
\hline Environmental & Changes in SE US forest structure and composition & Olesen et al. (2016) & - & & \\
\hline Socioeconomic & $\begin{array}{l}\text { Local competition for low-cost biomass as domestic and } \\
\text { international markets fluctuate }\end{array}$ & $\begin{array}{l}\text { Spelter and Toth (2009), Stasko et al. } \\
\text { (2011), Stewart (2015) }\end{array}$ & - & - & \\
\hline Socioeconomic & $\begin{array}{l}\text { Growth in sustainable green economy jobs relative to } \\
\text { boom-bust cycle of extractive nonrenewable energy } \\
\text { alternatives }\end{array}$ & Parish et al. (2013) & + & & - \\
\hline Socioeconomic & $\begin{array}{l}\text { Changes in SE US forest management practices (e.g., } \\
\text { rotation length, thinning, residue removal rates) }\end{array}$ & $\begin{array}{l}\text { Dwivedi et. al. (2014), Fritts et al. } \\
\text { (2015) }\end{array}$ & 0 & & \\
\hline Socioeconomic & Impacts on recreation and hunting during harvests & $\begin{array}{l}\text { Personal communication to E. S. } \\
\text { Parish from attendees of the } \\
\text { Appalachian Wood Energy } \\
\text { Innovations Conference on } 24 \text { August } \\
2016\end{array}$ & 0 & & \\
\hline
\end{tabular}

(Olesen et al. 2016). The UK and Belgium have already implemented sustainability regulations for the whole biomass supply chain (Goh et al. 2013), and the Netherlands has been examining this issue (Kotrba 2017).

Negative socioeconomic effects of the pellet trade on the receiving system include higher costs of wood pellets relative to coal (June 2015 price differences were USD \$165/MT of wood pellets vs. $\$ 58 / \mathrm{MT}$ of coal) and the costs associated with boiler conversion (Green 2015). Benefits to Europe include improved local air quality due to fewer toxins released to the atmosphere during combustion of wood relative to coal (Dwivedi et al. 2014), the preservation of EU forested lands and their associated ecosystem services (Solberg et al. 2014), and job creation because it takes more people to provision a power plant with pellet fuel than with coal (Strauss 2014).

\section{Spillover system: the decline of coal}

Britain celebrated its first completely coal-free electricity day since 1881 on 21 April 2017 (BBC News 2017). UK biomass capacity has increased 16-fold while coal-fired generation has dropped $88 \%$ since 2010 (Voegele 2016). There has been a waning of U.S. coal shipments to the UK and Belgium and a leveling off of coal shipments to the Netherlands at the same time that wood pellet shipments to the EU have increased for biopower production (Fig. 4). U.S. coal production and energy usage declined slightly from nearly 1.1 billion metric tons in 2008 to approximately 816 million metric tons in 2015, whereas U.S. coal exports shifted away from Europe toward China, South Korea, and other countries (U.S. Energy Information Administration 2016).

Although we have identified the U.S. coal industry as a spillover system within this telecoupling framework (Fig. 1), the drop in
European coal imports from the United States is related to additional factors beyond wood pellets. A recent news article stated that Europe has decreased its imports of coal from the U. S. region of Appalachia by $50 \%$ over the past five years due, in part, to a growing market of renewables (Breen and Koehler 2017). Our analysis of EUROSTAT Energy Balances data provided by EU member states (Fig. 5) indicates that the combined total primary energy production for the UK, Belgium, and the Netherlands has been declining since 2000, and that the proportion of primary energy produced from renewable resources (e.g., wind and solar) has grown faster than the proportion of primary energy produced from solid biofuels. These EU member states continue to produce energy from a variety of nonrenewable resources other than coal, including natural gas, oil, and nuclear power (European Commission 2017). Further research will be required to isolate and quantify the effects of increasing wood pellet use in Europe on the U.S. coal industry.

Additional spillover effects from the wood pellet trade include pollutant emissions to the global atmosphere and the Atlantic Ocean during shipments of pellets to Europe (Fig. 1). Dwivedi et al. (2011) calculated that transportation across the ocean is the largest source of GHG emissions from the supply chain, amounting to $71,750 \mathrm{MT}$ of carbon dioxide equivalent per shipment from Florida to the Netherlands, or $44 \%$ of the carbon dioxide equivalent emissions generated from tree production through power plant combustion. However, it is unclear whether transatlantic shipments have increased due to the wood pellet trade or if the tankers are simply transporting the pellets in place of something else (e.g., coal). 
Fig. 4. (A) U.S. coal exports to the three largest European importers of Southeast U.S. (SE US) wood pellets, namely the UK, the Netherlands, and Belgium (USITC 2017). (B) SE US wood pellet exports to these three European Union member states (USITC 2017) accelerated at about the same time that U. S. coal exports began to slow or decline. However, the decline in U.S. coal exports to Europe has resulted from factors additional to increased wood pellet use.
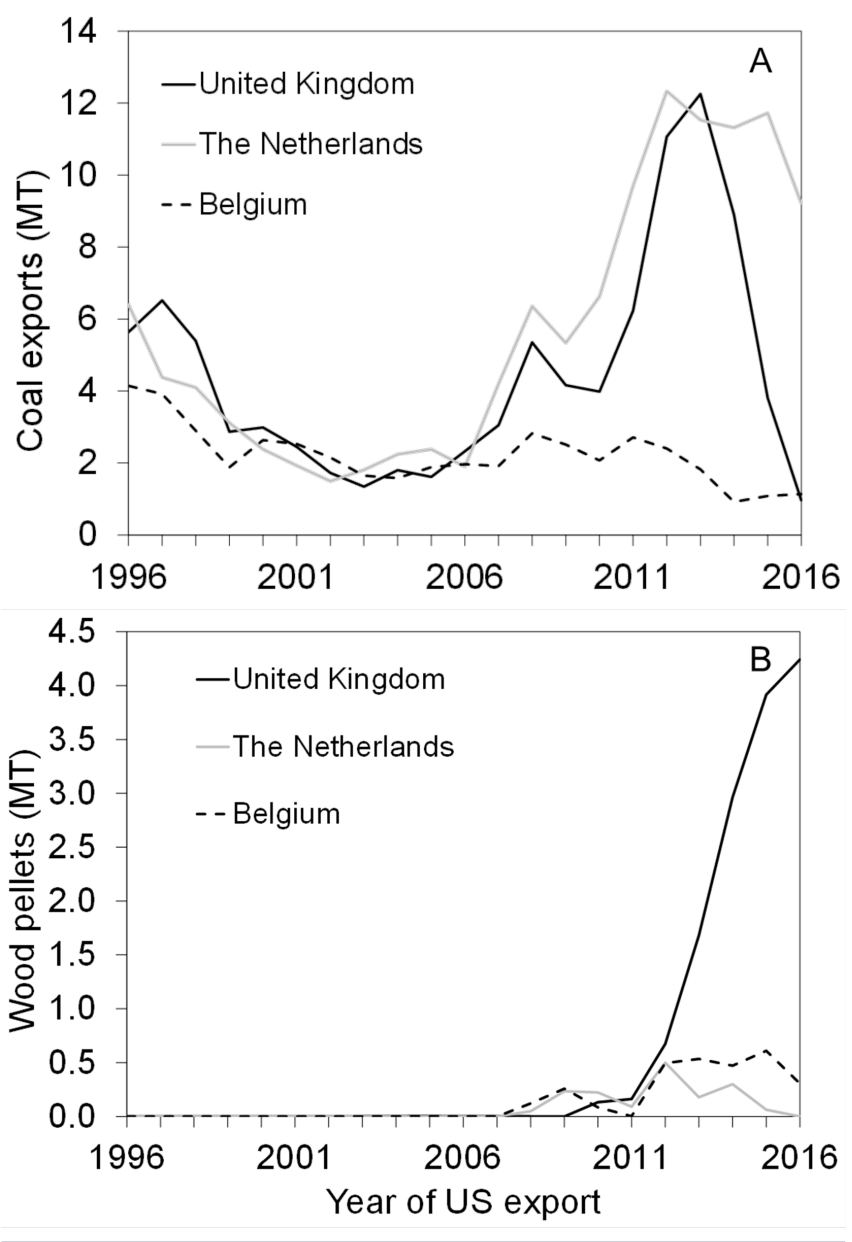

\section{KNOWLEDGE GAPS AND FUTURE UNCERTAINTIES}

The future trajectory of the transatlantic wood pellet trade is currently unclear. Several recent political decisions, in both the United States and Europe, have significant potential to affect the overall wood pellet trade system. The European Commission has recently proposed an increase in its renewable energy target to $27 \%$ by 2030 , making it possible that the EU will need to import more wood pellets from the United States (Olesen et al. 2016). However, recent austerity measures by the EU and its member states have capped subsides for all renewables, making it harder for new export pellet mills to secure long-term contracts with European customers (Stewart 2015). The so-called "Brexit" decision by the UK to depart the EU has many people wondering if the UK, the largest importer of SE US pellets, will soon decrease its demand for wood-based energy. U.S. President Trump's recent decision to remove the United States from the Paris Agreement complicates the U.S. pellet export situation because the EU does not intend to accept pellets from nations that are not part of that international climate agreement (Murray 2017). However, the fact that many European power plants have already made the necessary conversions from coal to biomass and have established long-term contracts with wood suppliers in the SE US suggests that the EU may find a way to continue this trade arrangement so that renewable energy consumers do not end up facing "disproportionate burdens and costs" (Council of the European Union 2017). During 2018, EU member states will be debating the proposed Renewable Energy Directive (RED II) and whether it will allow the United States to continue exporting wood pellets to the EU if suppliers choose to meet a set of sustainability requirements (Ginther 2017).

Fig. 5. Primary energy generation from solid biomass relative to other renewable and nonrenewable fuel sources used in the UK, the Netherlands, and Belgium (European Commission 2017b). By European Union definition, solid biomass includes pellets, chips, and bales (Giuntoli et al. 2017). Other renewables include hydropower, wind, solar, and electricity generation from gaseous and liquid biofuels, renewable municipal waste, geothermal, and tide, wave and ocean (European Commission 2017b). Nonrenewables include fossil fuels such as oil, coal, and natural gas, as well as nuclear resources (European Commission 2017b).

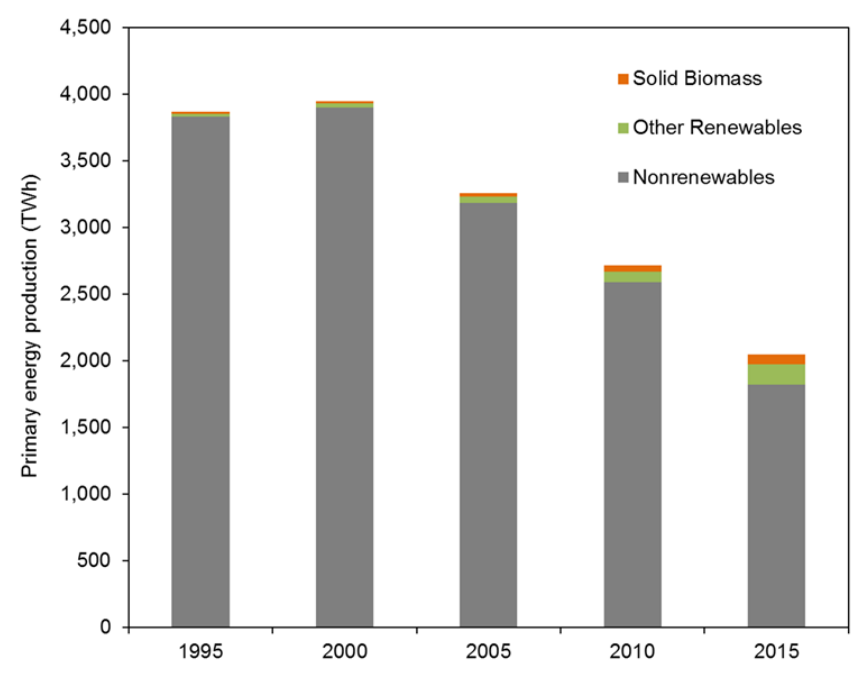

Biomass suppliers report in trade industry journals that they anticipate continued growth in wood pellet trade with the UK over the near term despite Brexit (Wood Resources International 2016). The total production capacity of existing SE US export pellet mills is 7.4 MT/yr (Stewart 2015), so there is room to grow beyond the 4.6 MT of pellets exported in 2015. If the EU market for SE US wood pellets does decline, there are other potential markets available, both locally and abroad (Arnold 2016).

Forest management concerns raised by rapid growth of the wood pellet export industry are similar to the issues raised when a large number of chip mills began to proliferate across the SE US during 1985-2000 (Stewart 2015). Despite the fears expressed by NGOs, 
clearcutting did not become widespread, and harvest rotation lengths did not shorten during the chip mill boom (Schaberg et al. 2005, Stewart 2015). An integrated assessment of wood chip production in North Carolina found that chip mills should be viewed as "a processing technology rather than an independent cause of timber harvesting" (Schaberg et al. 2005:17). We envision a similar outcome for the transatlantic wood pellet export market given its small share of the overall SE US wood market and the multitude of regulations and state-based BMPs in place to ensure sustainable forest management at regional and local scales.

\section{CONCLUSION}

Based on our analysis using the telecoupled framework, we conclude that assertions of negative ecological impacts on SE US forests are not currently substantiated (as demonstrated by the observed effects listed in Table 5). We also find that the transatlantic wood pellet trade is an example of a mutually beneficial telecoupled system with the potential to provide environmental as well as socioeconomic benefits in both the SE US and Europe. Given that biomass for wood pellets comprises only $3 \%$ of SE US timberland removals, however, it is profoundly difficult to isolate the effects of wood pellet production from those of the SE US wood industry as a whole (Parish et al. 2017a,b). Against the current backdrop of plentiful natural gas (in the United States) and increasing renewable energy use (worldwide), it is extremely difficult to isolate the effects of wood pellets on the U.S. coal industry's current downward trajectory.

Some of the controversy surrounding this renewable energy pathway has arisen due to the large number of agents involved in the transatlantic wood pellet trade, many of whom have different definitions of the alternative (or reference) case of forest management in the absence of the pellet trade (Parish et al. 2017b). During this case study, we extended the telecoupling framework by subdividing agents. We delineated between decision-making (primary) agents who operate in this connected system and those who facilitate, but are not essential to, the magnitude of the flow between the sending and receiving systems. We also found it useful to highlight those constraining agents that can inhibit or slow the telecoupled relationships in either the sending or receiving systems. This refined understanding of agents helps to identify stakeholders who influence the telecoupled relationships found within this complex system. Agents' roles can cross system boundaries and be time or case specific, evolving as the systems reacts to feedbacks.

Previous studies of the transatlantic wood pellet trade have typically focused on life cycle analysis of GHG emissions, but using the telecoupling framework helped us to integrate information from across many disciplines to address the transatlantic wood pellet trade holistically and reveal environmental, social, and economic benefits in both the sending and receiving systems (Table 5). Further research is needed to quantify all of the interactions and effects identified through this analysis so that a model can be developed for evidence-based decision making with regard to the sustainability of this bioenergy pathway. Continued monitoring of SE US forests is essential for determining whether the potential environmental and socioeconomic effects (Table 6) of the wood pellet trade are realized in the future.
Responses to this article can be read online at: http://www.ecologyandsociety.org/issues/responses. $\mathrm{php} / 9878$

\section{Acknowledgments:}

This manuscript resulted from the collaboration of authors $E S, A H$, and CP during an April 2016 Telecoupling Workshop hosted by Dr. Jack Liu at the Annual Meeting of the U.S. Regional Association of the International Association for Landscape Ecology (USIALE) in Asheville, North Carolina, USA. Authors ES and VD were supported by the U.S. Department of Energy (DOE) under the Bioenergy Technologies Office. Oak Ridge National Laboratory (ORNL) is managed by UT-Battelle for the DOE under contract DE-AC05-00OR22725. Author CP was supported by NSF PIRE grant 1243444. We thank Keith Kline of ORNL and three anonymous reviewers for their constructive comments. We also thank Keith Kline for his role in shaping many of the data analyses and ideas discussed in this paper.

\section{LITERATURE CITED}

Abt, K. L., R. C. Abt, C. S. Galik, and K. E. Skog. 2014. Effect of polices on pellet production in the U.S.: a technical document supporting the Forest Service update of the 2010 RPA assessment. General Technical Report SRS-202. U.S. Department of Agriculture Forest Service, Southern Research Station, Asheville, North Carolina, USA. [online] URL: https://www.srs.fs.usda. gov/pubs/47281

Achat, D. L., M. Fortin, G. Landmann, B. Ringeval, and L. Augusto. 2015. Forest soil carbon is threatened by intensive biomass harvesting. Scientific Reports 5:15991. http://dx.doi. org/10.1038/srep15991

Anderson, N., and D. Mitchell. 2016. Forest operations and woody biomass logistics to improve efficiency, value, and sustainability. Bioenergy Research 9(2):518-533. http://dx.doi. org/10.1007/s12155-016-9735-1

Arnold, H. 2016. The future of pellets. World Biomass 2016/2017:42-43.

BBC News. 2017. First coal-free day in Britain since 1880s. $B B C$ News Services 22 April 2017. [online] URL: http://www.bbc.com/ news/uk-39675418

Beckman, J. 2015. Biofuel use in international markets: the importance of trade. EIB-144. U.S. Department of Agriculture, Economic Research Service, Washington, D.C., USA. [online] URL: https://www.ers.usda.gov/publications/pub-details/?pubid=44012

Berndes, G., B. Abt, A. Asikainen, A. Cowie, V. Dale, G. Egnell, M. Lindner, L. Marelli, D. Paré, K. Pingoud, and S. Yeh. 2016. Forest biomass, carbon neutrality and climate change mitigation. From Science to Policy 3. European Forest Institute, Joensuu, Finland. [online] URL: http://www.alphagalileo.org/AssetViewer. aspx?AssetId $=116589 \&$ CultureCode $=$ en

Brandeis, C., and Z. Guo. 2016. Decline in the pulp and paper industry: effects on backward-linked forest industries and local 
economies. Forest Products Journal 66(1-2):113-118. http://dx. doi.org/10.13073/FPJ-D-14-00106

Breen, M., and J. Koehler. 2017. Trump's plan for clean energy will damage economy, national security. Renewable Energy World 18 April 2017. [online] URL: http://www.renewableenergyworld. com/articles/2017/04/trump-s-plan-for-clean-energy-will-damageeconomy-national-security.html

Buchholz, T., V. A. Luzadis, and T. A. Volk. 2009. Sustainability criteria for bioenergy systems: results from an expert survey. Journal of Cleaner Production 17(S1):S86-S98. https://doi. org/10.1016/j.jclepro.2009.04.015

Butler, S. M., B. J. Butler, and M. Markowski-Lindsay. 2017. Family forest owner characteristics shaped by life cycle, cohort, and period effects. Small-scale Foresty 16(1):1-18. https://doi. org/10.1007/s11842-016-9333-2

Cornwall, W. 2017. Is wood a green source of energy? Scientists are divided. Science 355(6320):18-21. http://dx.doi.org/10.1126/ science.aal0574

Costanza, J. K., R. C. Abt, A. J. McKerrow, and J. A. Collazo. 2016. Bioenergy production and forest landscape change in the southeastern United States. Global Change Biology Bioenergy 9 (5):924-939. http://dx.doi.org/10.1111/gcbb.12386

Coulston, J. W., D. N. Wear, and J. M. Vose. 2015. Complex forest dynamics indicate potential for slowing carbon accumulation in the southeastern United States. Scientific Reports 5:8002. http:// dx.doi.org/10.1038/srep08002

Council of the European Union. 2017. Proposal for a directive of the European Parliament and of the Council on the promotion of the use of energy from renewable sources (recast). Interinstitutional File 2016/0382 (COD). 8697/1/17 REV 1. General Secretariat of the Council, Brussels, Belgium. [online] URL: http://data.consilium.europa.eu/doc/document/ST-8697-2017$\underline{\mathrm{REV}-1 / \mathrm{en} / \mathrm{pdf}}$

Cristan, R., W. M. Aust, M. C. Bolding, S. M. Barrett, J. F. Munsell, and E. Schilling. 2016. Effectiveness of forestry best management practices in the United States: literature review. Forest Ecology and Management 360:133-151. http://dx.doi. org/10.1016/j.foreco.2015.10.025

Dale, V. H., K. L. Kline, E. S. Parish, A. L. Cowie, R. Emory, R. W. Malmsheimer, R. Slade, C. T. Smith Jr., T. B. Wigley, N. S. Bentsen, G. Berndes, P. Bernier, M. Brandão, H. L. Chum, R. Diaz-Chavez, G. Egnell, L. Gustavsson, J. Schweinle, I. Stupak, P. Trianosky, A. Walter, C. Whittaker, M. Brown, G. Chescheir, I. Dimitriou, C. Donnison, A. G. Eng, K. P. Hoyt, J. C. Jenkins, K. Johnson, C. A. Levesque, V. Lockhart, M. C. Negri, J. E. Nettles, and M. Wellisch. 2017a. Status and prospects for renewable energy using wood pellets from the southeastern United States. Global Change Biology Bioenergy 9(8):1296-1305. http://dx.doi.org/10.1111/gcbb.12445

Dale, V. H., E. S. Parish, K. L. Kline, and E. Tobin. 2017b. How is wood-based pellet production affecting forest conditions in the southeastern United States? Forest Ecology and Management 396:143-149. https://doi.org/10.1016/j.foreco.2017.03.022
Davis, M. B., editor. 1996. Eastern old growth forests: prospects for rediscovery and recovery. Island Press, Washington, D.C., USA.

Drax Biomass. 2016a. Drax Biomass collaborates to protect Louisiana wetlands. Biomass Magazine 20 October 2016. [online] URL: http://biomassmagazine.com/articles/13825/drax-biomasscollaborates-to-protect-louisiana-wetlands

Drax Biomass. 2016b. The biomass story. Drax Biomass, Atlanta, Georgia, USA. [online] URL: https://www.drax.com/wpcontent/uploads/2016/09/The-Biomass-Story1.pdf

Dwivedi, P., R. Bailis, T. G. Bush, and M. Marinescu. 2011. Quantifying GWI of wood pellet production in the southern United States and its subsequent utilization for electricity production in The Netherlands/Florida. Bioenergy Research 4 (3):180-192. http://dx.doi.org/10.1007/s12155-010-9111-5

Dwivedi, P., M. Khanna, R. Bailis, and A. Ghilardi. 2014. Potential greenhouse gas benefits of transatlantic wood pellet trade. Environmental Research Letters 9(2):024007. http://dx.doi. org/10.1088/1748-9326/9/2/024007

European Academies Science Advisory Council (EASAC). 2017. Multi-functionality and sustainability in the European Union's forests. EASAC Policy Report 32. EASAC, Halle (Saale), Germany. [online] URL: http://www.easac.eu/fileadmin/PDF s/ reports statements/Forests/EASAC Forests web complete.pdf

European Commission. 2017. Energy balances in the MS Excel file format (2017 edition). Eurostat, European Commission, Luxembourg. [online] URL: http://ec.europa.eu/eurostat/web/ energy/data/energy-balances

European Parliament. 2009. Directive 2009/28/EC of the European Parliament and of the Council of 23 April 2009 on the promotion of the use of energy from renewable sources and amending and subsequently repealing Directives 2001/77/EC and 2003/30/EC. Official Journal of the European Union L 140/16: 5.6.2009. Publications Office, Luxembourg. [online] URL: $\underline{\text { http:// }}$ data.europa.eu/eli/dir/2009/28/oj

Evans, A. M., R. T. Perschel, and B. A. Kittler. 2013. Overview of forest biomass harvesting guidelines. Journal of Sustainable Forestry 32(1-2):89-107. http://dx.doi.org/10.1080/10549811.2011.651786

Food and Agriculture Organization (FAO). 2017. FAOSTATforestry database. Food and Agriculture Organization, Rome, Italy. [online] URL: http://www.fao.org/forestry/statistics/84922/ en/

Fritts, S. R., C. E. Moorman, S. M. Grodsky, D. W. Hazel, J. A. Homyack, C. B. Farrell, and S. B. Castleberry. 2015. Shrew response to variable woody debris retention: implications for sustainable forest bioenergy. Forest Ecology and Management 336:35-43. http://dx.doi.org/10.1016/j.foreco.2014.10.009

Ginther, M. S. 2017. Opinion: Setting the record straight on the Paris Agreement. Biomass Magazine 8 June 2017. [online] URL: http://www.biomassmagazine.com/articles/14437/opinion-settingthe-record-straight-on-the-paris-agreement

Giuntoli, J., A. Agostini, R. Edwards, and L. Marelli. 2017. Solid and gaseous bioenergy pathways: input values and GHG emissions: 
calculated according to the methodology set in COM(2016) 767: Version 2. EUR 27215 EN. Publications Office, Luxembourg. http://dx.doi.org/10.2790/27486

Goh, C. S., M. Junginger, M. Cocchi, D. Marchal, D. Thrän, C. Hennig, J. Heinimö, L. Nicolaisen, P.-P. Schouwenberg, D. Bradley, R. Hess, J. Jacobson, L. Ovard, and M. Deutmeyer. 2013. Wood pellet market and trade: a global perspective. Biofuels, Bioproducts, and Biorefining 7(1):24-42. http://dx.doi.org/10.1002/ $\underline{\text { bbb. } 1366}$

Green, W. 2015. Converting Drax to burn biomass required new supply chain. Supply Management 22 June 2015. [online] URL: https://www.cips.org/supply-management/news/2015/june/convertingdrax-to-burn-biomass-required-new-supply-chain/

Greenberg, C. H., and B. S. Collins, editors. 2016. Natural disturbances and historic range of variation: type, frequency, severity, and post-disturbance structure in central hardwood forests USA. Springer, Cham, Switzerland. https://doi.org/10.1007/978$\underline{-3-319-21527-3}$

Hamilton, D. S., and J. P. Quinlan. 2017. The transatlantic economy 2017: annual survey of jobs, trade and investment between the United States and Europe. American Chamber of Commerce to the European Union, Brussels, Belgium. [online] URL: http:// www.amchameu.eu/sites/default/files/170227 full-book.pdf

Hanula, J. L., S. Horn, and J. J. O’Brien. 2015. Have changing forests conditions contributed to pollinator decline in the southeastern United States? Forest Ecology and Management 348:142-152. https://doi.org/10.1016/j.foreco.2015.03.044

Intergovernmental Panel on Climate Change. 2014. Climate change 2014: mitigation of climate change. Contribution of Working Group III to the Fifth Assessment Report of the Intergovernmental Panel on Climate Change (O. Edenhofer, R. Pichs-Madruga, Y. Sokona, E. Farahani, S. Kadner, K. Seyboth, A. Adler, I. Baum, S. Brunner, P. Eickemeier, B. Kriemann, J. Savolainen, S. Schlömer, C. von Stechow, T. Zwickel, and J. C. Minx, editors). Cambridge University Press, Cambridge, UK. [online] URL: http://www.ipcc.ch/report/ar5/wg3/

Jandl, R., M. Lindner, L. Vesterdal, B. Bauwens, R. Baritz, F. Hagedorn, D. W. Johnson, K. Minkkinen, and K. A. Byrne. 2007. How strongly can forest management influence soil carbon sequestration? Geoderma 137(3-4):253-268. https://doi.org/10.1016/ j.geoderma.2006.09.003

Janowiak, M. K., and C. R. Webster. 2010. Promoting ecological sustainability in woody biomass harvesting. Journal of Forestry 108(1):16-23.

Joly, C. A., B. J. Huntley, L. M. Verdade, V. H. Dale, G. Mace, B. Muok, and N. H. Ravindranath. 2015. Biofuel impacts on biodiversity and ecosystem services. Pages 554-581 in G. M. Souza, R. L. Victoria, C. A. Joly, and L. M. Verdade, editors. Bioenergy and sustainability: bridging the gaps. Scientific Committee on Problems of the Environment, Paris, France. [online] URL: http://bioenfapesp.org/scopebioenergy/index.php

Kotrba, R. 2017. Stimulating sustainability certification in North America. Biomass Magazine 02 June 2017. [online] URL: http:// biomassmagazine.com/articles/14404/stimulating-sustainabilitycertification-in-north-america
Krč, J., A. Taylor, and D. Hodges. 2016. Paying for what you get: accounting for the nonrenewable component in wood to energy. Forest Products Journal 66(7-8):384-390. http://dx.doi.org/10.13073/ FPJ-D-15-00081

Langholtz, M. H., B. J. Stokes, and L. M. Eaton. 2016. 2016 billion-ton report: advancing domestic resources for a thriving bioeconomy. DOE/EE-1440 7439. U.S. Department of Energy, Washington, D.C., USA. http://dx.doi.org/10.2172/1271651

Liu, J., V. Hull, M. Batistella, R. DeFries, T. Dietz, F. Fu, T. W. Hertel, R. C. Izaurralde, E. F. Lambin, S. Li, L. A. Martinelli, W. J. McConnell, E. F. Moran, R. Naylor, Z. Ouyang, K. R. Polenske, A. Reenberg, G. de Miranda Rocha, C. S. Simmons, P. H. Verburg, P. M. Vitousek, F. Zhang, and C. Zhu. 2013. Framing sustainability in a telecoupled world. Ecology and Society 18 (2):26. http://dx.doi.org/10.5751/ES-05873-180226

Liu, J., H. Mooney, V. Hull, S. J. Davis, J. Gaskell, T. Hertel, J. Lubchenco, K. C. Seto, P. Gleick, C. Kremen, and S. Li. 2015. Systems integration for global sustainability. Science 347:1258832. http://dx.doi.org/10.1126/science.1258832

Malmsheimer, R., and K. Fernholz. 2015. How laws, practices, and markets ensure sustainable forest biomass feedstocks from the Southeast U.S. World Biomass 2015/2016:8-12.

Mei, B., and M. Wetzstein. 2017. Burning wood pellets for US electricity generation? A regime switching analysis. Energy Economics 65:434-441. http://dx.doi.org/10.1016/j.eneco.2017.05.025

Morrison, B., and J. S. Golden. 2018. Southeastern United States wood pellets as a global energy resource: a cradle-to-gate life cycle assessment derived from empirical data. International Journal of Sustainable Energy 37(2):134-146. http://dx.doi.org/10.1080/147$\underline{86451.2016 .1188816}$

Murray, G. 2017. Pulling out of Paris: the effect on the U.S. wood pellet industry. Canadian Biomass 2 June 2017. [online] URL: https://www.canadianbiomassmagazine.ca/pellets/pulling-out-ofparis-the-effect-on-the-us-wood-pellet-industry-6303

Natural Resources Defense Council (NRDC). 2015. In the U.S. Southeast, natural forests are being felled to send fuel overseas. R-15-10-A. NRDC, New York, New York, USA. [online] URL: https://www.nrdc.org/sites/default/files/southeast-biomass-exportsreport.pdf

Neary, D. G., and E. J. Zieroth. 2007. Forest bioenergy system to reduce the hazard of wildfires: White Mountains, Arizona. Biomass and Bioenergy 31:638-645. https://doi.org/10.1016/j. biombioe.2007.06.028

O’Connell, B. M., B. L. Conkling, A. M. Wilson, E. A. Burrill, J. A. Turner, S. A. Pugh, G. Christensen, T. Ridley, and J. Menlove. 2014. The Forest Inventory and Analysis database: database description and user guide for phase 2 (version 6.1). U.S. Department of Agriculture Forest Service, Washington, D.C., USA. http://dx.doi.org/10.2737/FS-FIADB-P2-6.1

Olesen, A. S., S. L. Bager, B. Kittler, W. Price, and F. Aguilar. 2016. Environmental implications of increased reliance of the $E U$ on biomass from the South East US: final report. ENV.B.1/ ETU/2014/0043. European Commission, Publications Office, Luxembourg. http://dx.doi.org/10.2779/30897 
Oswalt, S. N., and W. B. Smith, editors. 2014. U.S. forest resource facts and historical trends. U.S. Department of Agriculture Forest Service Report FS-1035. U.S. Department of Agriculture Forest Service, Washington, D.C., USA. [online] URL: https:/www.fs. fed.us/sites/default/files/legacy_files/media/types/publication/field_pdf/ forestfacts-2014aug-fs1035-508complete.pdf

Parish, E. S., V. H. Dale, and K. L. Kline. 2017a. Has pellet production affected southeastern US forests? World Biomass 2017:38-42.

Parish, E. S., V. H. Dale, K. L. Kline, and R. C. Abt. $2017 b$. Reference scenarios for evaluating wood pellet production in the southeastern United States. WIREs Energy and Environment 6(6): e259. http://dx.doi.org/10.1002/wene.259

Parish, E. S., K. L. Kline, V. H. Dale, R. A. Efroymson, A. C. McBride, T. L. Johnson, M. R. Hilliard, and J. M. Bielicki. 2013. Comparing scales of environmental effects from gasoline and ethanol production. Environmental Management 51(2):307-338. https://doi.org/10.1007/s00267-012-9983-6

Poudyal, N. C., R. L. Moore, and T. M. Young. 2015. Public attitudes toward regulatory and incentive approaches to private forests: an assessment and comparison of resident segments in Georgia, USA. Forest Science 61(6):1088-1096. http://dx.doi. org/10.5849/forsci.14-122

Ricardo Energy and Environment. 2016. Use of North American woody biomass in UK electricity generation: assessment of high carbon biomass fuel sourcing scenarios: technical report. Report ED60674, Issue 5. Ricardo Energy and Environment, Harwell, UK. [online] URL: https://www.gov.uk/government/uploads/ system/uploads/attachment data/file/600477/

PED60674 final report 270416 Tec Report FINAL v2 AMENDMENTS ACCEPTED.pdf

Rodrique, J.-P. 2016. Main maritime shipping routes. Department of Global Studies and Geography, Hofstra University, New York, New York, USA. [online] URL: https://people.hofstra.edu/ geotrans/eng/ch3en/conc3en/main_maritime_shipping_routes.html

Rudie, A. W., C. J. Houtman, L. H. Groom, D. L. Nicholls, and J. Y. Zhu. 2016. A survey of bioenergy research in Forest Service research and development. BioEnergy Research 9:534-547. https://doi.org/10.1007/s12155-016-9731-5

Schaberg, R. H., P. B. Aruna, F. W. Cubbage, G. R. Hess, R. C. Abt, D. D. Richter, S. T. Warren, J. D. Gregory, A. G. Snider, S. Sherling, and W. Flournoy. 2005. Economic and ecological impacts of wood chip production in North Carolina: an integrated assessment and subsequent applications. Forest Policy and Economics 7(2):157-174. http://dx.doi.org/10.1016/S1389-9341 (03)00029-7

Solberg, B., L. Hetemäki, A. M. I. Kallio, A. Moiseyev, and H. K. Sjølie. 2014. Impacts of forest bioenergy and policies on the forest sector markets in Europe - What do we know? EFI Technical Report 89. European Forest Institute, Joensuu, Finland. [online] URL: http://www.efi.int/files/attachments/publications/ efi tr89 2014 solberg et al.pdf

Spelter, H., and D. Toth. 2009. North America's wood pellet sector. Research Paper FPL-RP-656. U.S. Department of Agriculture
Forest Service, Forest Products Laboratory, Madison, Wisconsin, USA. http://dx.doi.org/10.2737/FPL-RP-656

Stasko, T. H., R. J. Conrado, A. Wankerl, R. Labatut, R. Tasseff, J. T. Mannion, H. O. Gao, S. D. Sanborn, and G. Knott. 2011. Mapping woody-biomass supply costs using forest inventory and competing industry data. Biomass and Bioenergy 35(1):263-271. http://dx.doi.org/10.1016/j.biombioe.2010.08.044

Stewart, P. 2015. Wood supply market trends in the US South: 1995-2015. Forest2Market, Charlotte, North Carolina, USA. [online] URL: http://www.theusipa.org/Documents/ USSouthWoodSupplyTrends.pdf

Strauss, W. 2014. The many benefits of replacing coal with wood pellet fuel. Biomass Magazine 12 August 2014. [online] URL: http://biomassmagazine.com/articles/10750/the-many-benefits-ofreplacing-coal-with-wood-pellet-fuel

Tarvainen, O., A.-M. Hekkala, E. Kubin, P. Tamminen, T. Murto, and A. Tolvanen. 2015. Soil disturbance and early vegetation response to varying intensity of energy wood harvest. Forest Ecology and Management 348:153-163. http://dx.doi.org/10.1016/ j.foreco.2015.04.001

U.S. Department of Commerce International Trade Administration. 2016. Biomass wood pellets, renewable fuels sector snapshot, 2016 top markets report. U.S. Department of Commerce International Trade Administration, Washington, D.C., USA. [online] URL: https://www.trade.gov/topmarkets/pdf/Renewable_Fuels_Biomass Wood Pellets.pdf

U.S. Energy Information Administration. 2016. Annual coal report 2015. U.S. Department of Energy, Washington, D.C., USA. [online] URL: https://www.eia.gov/coal/annual/archive/05842015. pdf

U.S. Industrial Wood Pellet Association(USIPA). 2013. Industrial wood pellets: abundant. Sustainable. Carbon beneficial. Media kit prepared by the U.S. Industrial Wood Pellet Association, Richmond, Virginia, USA.

U.S. International Trade Commission (USITC). 2017. Interactive tariff and trade dataweb. U.S. International Trade Commission, Washington, D.C., USA. [online] URL: https://dataweb.usitc. gov/

Voegele, E. 2016. More than half of UK electricity sourced from low-carbon sources. Biomass Magazine 17 November 2016. [online] URL: http://biomassmagazine.com/articles/13933/morethan-half-of-uk-electricity-sourced-from-low-carbon-sources

Wear, D. N., R. Huggett, R. Li, B. Perryman, and S. Liu. 2013. Forecasts of forest conditions in regions of the United States under future scenarios: a technical document supporting the Forest Service 2012 RPA assessment. General Technical Report SRS-GTR-170. U.S. Department of Agriculture Forest Service, Southern Research Station, Asheville, North Carolina, USA. [online] URL: http://www.srs.fs.usda.gov/pubs/43055\#sthash.IIXY3o4O.dpuf

Weir, D. N., and J. G. Greis. 2013. The southern forest futures project: technical report. General Technical Report SRSGTR-178. U.S. Department of Agriculture Forest Service, Southern Research Station, Asheville, North Carolina, USA. [online] URL: https://www.srs.fs.usda.gov/pubs/44183 
Wood Resources International. 2016. UK wood pellet imports expected to reach new record in 2016. Biomass Magazine 02 November 2016. [online] URL: http://biomassmagazine.com/ articles/13866/uk-wood-pellet-imports-expected-to-reach-new-recordin-2016

Xian, H., G. Colson, B. Mei, and M. E. Wetzstein. 2015. Co-firing coal with wood pellets for U.S. electricity generation: a real options analysis. Energy Policy 81(1):106-116. https://doi. org/10.1016/j.enpol.2015.02.026 